\title{
PENGARUH PEMANFAATAN SUMBER BELAJAR PERPUSTAKAAN DAN PENGETAHUAN TENTANG TEORI MUSIK DENGAN BERMAIN ALAT MUSIK ORGAN
}

\author{
LINCE RAULI TURE SIMAMORA \\ Institut Agama Kristen Negeri Tarutung \\ Email: lince.simamora@yahoo.co.id
}

\begin{abstract}
Abstrak
Penelitian ini bertujuan untuk mengetahui pengaruh pemanfaatan sumber belajar perpustakaan dan pengetahuan tentang teori musik dengan bermain alat musik organ mahasiswa jurusan pendidikan musik gerejawi di IAKN Tarutung. Sampel penelitian ini berjumlah 55 orang. Teknik analis data digunakan adalah uji kuesioner serta study kepustakaan. Uji normalitas, uji multikolinieritas, uji heterokedastisitas, uji analisis regresi, linear berganda, uji hipotesis yang terdiri dari uji t uji f dan uji koevisien determian $\mathrm{R}^{2}$. Berdasarkan hasil diperoleh persamaan regresi sebagai berikut: Hasil Belajar Teori Musik $=4,165+0,250(X 1)+0,010(X 2)+E$. Nilai Adjusted $R$ Square diperoleh sebesar 0,430 atau sebesar 43\%, berarti $43 \%$ pengaruh variabel independen terhadap variabel dependen, sisanya $57 \%$ dipengaruhi oleh variabel lain. Hasil penelitian diperoleh bahwa secara stimulan pemanfaatan sumber belajar perpustakaan berpengaruh positif signifikan terhadap hasil belajar, pengetahuan teori musik berpengaruh positif signifikan. Menunjukkan variabel pemanfaatan sumber belajar perpustakaan dan pengetahuan teori musik mempengaruhi sebanyak $43 \%$ terhadap hasil belajar teori musik.
\end{abstract}

Kata kunci: Sumber belajar, bermain alat musik organ.

\section{PENDAHULUAN}

Kemajuan masyarakat modern dewasa ini tidak mungkin dicapai tanpa kehadiran kampus sebagai organisasi yang menyelenggarakan proses pendidikan secara formal. Namun kampus bukan satu-satunya lembaga yang menyelenggarakan pendidikan, karena masih ada institusi keluarga, dan pendidikan luar kampus. Justru semua institusi dimaksud harus berkolaborasi dalam mengoptimalkan pembinaan mahasiswa sebagai generasi penerus. Untuk itu, perlu dipahami dalam konsep yang luas lebih dari sekedar sistem lembaga formal.
Kegiatan pendidikan sebagai suatu gejala budaya dalam masyarakat telah berlangsung baik di rumah tangga, kampus atau sekolah maupun dimasyarakat. Kegiatan pendidikan yang berlangsung di kampus menempatkan kampus sebagai salah satu intitusi social yang keberadaannya berfungsi melaksanakan kegiatan pembinaan potensi mahasiswa dan transformasi budaya bangsa. Dalam kegiatan tersebut, dosen bertanggung jawab terhadap proses pengembangan kemampuan individualitas, moralitas dan sosialitas mahasiswa. Menjelaskan bahwa kampus diciptakan memberikan bagian penting pendidikan bagi generasi 
muda. Dosen memberi pemahaman materi kuliah kepada mahasiswa.

Pendidikan di kampus sebagai proses bimbingan yang terencana, terarah dan terpadu dalam membina potensi mahasiswa untuk menguasai ilmu pengetahuan, nilai-nilai dan keterampilan yang sangat menentukan corak masa depan bangsa. Di kampus mahasiswa dengan segala potensi dirinya juga dikembangkan untuk menjadi sumber daya mahasiswa unggul, sehingga melahirkan berbagai kreativitas untuk dapat berkembang dan bertahan hidup (survive). Peranan kampus berkaitan langsung dengan pengembangan sumber daya manusia. Setiap program pendidikan dikampus perlu diorientasikan kepada pemantapan proses pengembangan sumber daya manusia sebagai modal dasar pembangunan yang dilaksanakan oleh pemerintah bersama masyarakat. Pemberdayaan kampus sebagai wahana sosialisasi harus dapat dilakukan melalui pemberdayaan manajemen kampus dengan pengembangan kepemimpinan perangkat kampus yang efektif. Sedangkan pemberdayaan mahasiswa dalam belajar dapat dilakukan dengan memanfaatkan sumber belajar yang diarahkan oleh para dosen yang professional.

Jadi Kampus harus menjadi penyalur semua informasi, pengetahuan, sumber daya dan metodologi belajar, kampus juga menjadi tempat dan pusat pembelajaran, tempat kerja, dan pusat pemeliharaan (Syarifuddin \& Irwan, 2005).

Menghadapi tantangan pada era informasi dan perubahan social yang semakin cepat, pendidikan masa depan perlu sejak dini (mulai pendidikan dasar) melatih peserta didik untuk mampu belajar secara mandiri dengan memupuk sikap gemar membaca, mencari informasi baru dan meneliti serta memanfaatkan sumber-sumber belajar yang diperlukan untuk dapat menjawab persoalan-persoalan yang dihadapi. Transformasi dari masyarakat yang lamban, tidak kreatif dan bodoh kepada terbentuk nya masyarakat belajar (learning society) dengan kreativitas tinggi menjadi sasaran pembelajaran.

Rendahnya mutu pendidikan, khususnya jenjang pendidikan tinggi merupakan isu kritis dalam dunia pendidikan di Indonesia dewasa ini. Salah satu yang disoroti adalah perlunya melakukan perubahan paradigma pendidikan nasional untuk memberdayakan kampus menuju kampus yang lebih efektif. Perubahan manajemen pendidikan merupakan kata kunci bagi pemberdayaan seluruh sumber daya personil sekolah.

$$
\text { Inti pendidikan adalah }
$$

pembelajaran. Dengan pembelajaran terjadi perubahan tingkah laku. Melalui pendidikan terjadi perkembangan kepribadian. Kepribadian positif melahirkan tingkah laku yang baik. Jadi pembelajaran adalah bentuk konkrit pendidikan. Untuk menciptakan pembelajaran yang baik diperlukan alat pembelajaran yang meliputi komponen; kurikulum, teknologi pembelajaran dan alat bantu pembelajaran, lingkungan pembelajaran dan penilaian hasil pembelajaran, yang sering disebut juga strategi pembelajaran. Sedangkan untuk 
pendidikan yang baik dibutuhkan alat pendidikan yang meliputi komponen; kewibawaan, kasih sayang yang tulus, keteladanan, penguatan dan ketegasan yang mendidik. Ini disebut suatu proses yang mengandung atmosfir nilai paedagogis.

Pembelajaran di kampus harus berusaha mewujutdkan empat visi baru pendidikan di sekolah sebagaimana ditawarkan oleh UNESCO. Menjelaskan pendidikan abad ke-21 harus diorientasikan kepada pencapaian empat pilar pembelajaran, yaitu: Learning to know, Learning to do Learning to be dan Learning to live together, yang dilakukan dengan jalan mengembangkan segala potensi yang ada pada setiap pribadi.

Pembelajaran merupakan kegiatan utama kampus, yang dalam pelaksanaannya kampus diberi kebebasan memilih strategi, pendekatan, metode, teknik pembelajaran, yang paling efektif sesuai dengan karateristik mata kuliah, peserta didik, dosen serta kondisi nyata sumber daya yang tersedia dan siap didayagunakan di kampus. Pemilihan dan pengembangan strategi, pendekatan metode, teknik pembelajaran hendaknya berpusat pada karakteristik peserta didik, agar dapat melibatkan mereka secara aktif dan kreatif dalam pembelajaran, dengan senantiasa menekankan pada praktek yang dengan mendayagunakan masyarakat dan lingkungan sekitar kampus sebagai sumber belajar, khususnya dengan pemanfaatan perpustakaan sebagai sumber belajar serta dengan menumbuhkembangkan motivasi belajar. Berdasarkan hal diatas, perlu ditelaah secara sistematik terhadap pelaksanaan pembelajaran berorientasi pada kompetensi yang mulai di terapkan di semua jenjang kampus sejak dalam rangka perbaikan mutu pendidikan. Dalam hal ini perbaikan dan peningkatan hasil belajar teori musik mahasiswa.

Hasil belajar bermain alat musik Organ diharapkan menjadi prestasi belajar yang baik atau optimal. Namun dalam pencapaian hasil belajar yang baik masih mengalami kesulitan dan prestasi yang diperoleh belum dapat dicapai secara optimal. Dalam peningkatan hasil belajar pengetahuan tentang teori musik merupakan faktor yang paling penting. Pengetahuan tentang musik diperoleh mahasiswa setelah melaksanakan pembelajaran tentang teori musik yang baik dalam kelas maupun dengan memanfaatkan sumber belajar perpustakaan. Teori musik merupakan salah satu ilmu penentu dan dapat membantu mahasiswa dalam proses metode mengaransemen lagu dengan instrumen musik dan tentang pemahaman unsurunsur reportoar, wujud, motif, melodi, harmoni, tempo, pengenalan istilahistilah musik. Teori musik menjelaskan bagaimana suara dinotasikan atau dituliskan dan bagaimana suara tersebut diungkapkan dalam pendengaran.

Untuk itu, perlu dilakukan penelitian secara ilmiah untuk menjelaskan sejauh mana pelaksanaan pembelajaran serta pemanfaatan sumber belajar perpustakaan. Hal-hal apa yang sudah berjalan selama ini, dan hal apa yang belum berjalan dalam program 
peningkatan hasil belajar teori musik melalui pemanfaatan sumber belajar perpustakaan dan pemahaman teori musik para mahasiswa pada masa yang akan datang.

\section{METODE PENELITIAN}

Bentuk yang digunakan dalam penelitian ini adalah metode penelitian asosiatif dengan pendekatan kuantitatif. Penelitian dalam permasalahan asosiatif merupakan penelitian yang berupaya untuk mengkaji bagaimana suatu variabel memiliki keterkaitan atau hubungan dengan variabel lain, atau apakah suatu variabel dipengaruhi oleh variabel lainnya, atau apakah suatu variabel menjadi penyebab perubahan variabel menggunakan fungsi statistik. Dalam penilitian ini, peneliti ingin menguji Pengaruh Pemanfaatan Sumber Belajar Perpustakaan dan Pengetahuan Tentang Teori Musik dengan Bermain Alat Musik Organ

\section{HASIL PENELITIAN}

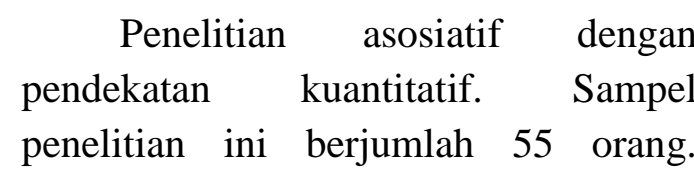
Teknikm pengumpumpulan data adalah penelitian yang terdiri dari kuesioner serta study kepustakaan. Teknik analis data yang digunakan adalah uji kuesioner serta study kepustakaan. teknik analisis yang digunakan adalah uji instrumen adalah uji validitas dan uji reabilitas serta metode analisis yang terdiri dari uji asumsi klasik yaitu uji normalitas, uji multikollinieritas, uji heterokedastisitas, uji analisis regresi, linear berganda, uji hipotesis yang terdiri dari uji t uji f dan uji koevisien determian $\mathrm{R}^{2}$ berdasarkan hasil penelitian ini, diperoleh persamaan regresi sebagai berikut: Hasil Belajar Teori Musik $=4,165+0,250(\mathrm{X} 1)+$ 0,010 (X2) + E. Konstanta (a) sebesar 4,165 apabila Pemanfaatan Sumber Belajar Perpustakaan (X1) dan Pengetahuan Tentang Teori Musik (X2) atau nilai variabel bebas adalah 0 , maka besarnya variabel keputusan pembelian adalah sebesar 4,165.

Variabel Pemanfaatan Sumber Belajar Perpustakaan (X1) terhadap hasil belajar teori musik dengan koefisien regresi sebesar 0,250. Apabila nilai setiap variabel pemanfaatan sumber belajar perpustakaan meningkat satu kesatuan maka nilai variabel hasil belajar teori musik akan bertambah sebesar 0,250

Variabel Pengetahuan Tentang Teori Musik (X2) terhadap hasil belajar teori musik dengan koefisien regresi sebesar 0,010. Apabila nilai setiap variabel pengetahuan tentang teori musik meningkat satu kesatuan maka nilai variabel keputusan pembelian akan bertambah sebesar 0,010.

\section{PEMBAHASAN}

Pengaruh Antara Pemanfaatan Sumber Belajar Perpustakaan Dengan Bermain Alat Musik Organ

Pemanfaatan sumber belajar perpustakaan merupakan hal pokok yang sangat penting dalam kegiatan pembelajaran. Dikatakan demikian, karena dengan pemanfaatan sumber belajar perpustakaan akan dapat membantu dan memberikan kesempatan belajar yang bervariasi serta dapat memberi pengalaman belajar yang kongkrit dan langsung. Dalam artian 
bahwa pemanfaatan sumber belajar perpustakaan secara optimal akan dapat meningkatkan prestasi belajar, sebab semakin banyak sumber belajar yang digunakan mahasiswa dalam belajar maka semakin tinggi prestasi belajar mahasiswa tersebut.

Dalam pemanfaatan sumber belajar perpustakaan mempelajari materi teori musik, dibutuhkan kreativitas juga upaya maksimal dosen mata kuliah maka hasil belajar teori musik dan keterampilan bermain alat musik organ jadi maksimal dan berhasil. Bervariasinya pemanfaatan sumber belajar perpustakaan dalam materi Teori musik dapat merangsang daya pikir dan daya belajar mahasiswa sehingga mahasiswa selalu berusaha mengembangkan dan meningkatkan kualitas bermain alat musik organ. karena melalui sumber belajar berupa buku-buku perkuliahan, teks book majalah, maupun buku buku Teori musik, mahasiswa di bimbing untuk menemukan dan memecahkan permasalahan pembelajaran yang dihadapi baik secara individual maupun kelompok.

Demikian juga dalam belajar bermain alat musik organ agar memperoleh kualitas bermain alat musik organ yang diinginkan harus di dukung oleh sarana belajar yang memadai serta ketersediaannya bahanbahan bacaan atau sumber belajar perpustakaan untuk dapat dimanfaatkan oleh para mahasiswa. Bila pemanfaatan sumber belajar perpustakaan tinggi kegiatan belajar pun cenderung meningkat dalam arti mahasiswa aktif dan sungguh-sungguh dalam belajar untuk mencapai hasil maksimal. Jika seseorang ingin berhasil dalam belajar maka ia harus aktif belajar untuk itu pemanfaatan sumber belajar perpustakaan perlu diefektifkan dalam setiap kegiatan belajar untuk meningkatkan hasil belajar dengan demikian jelas sekali bahwa semakin efektif pemanfaatan sumber belajar perpustakaan, maka diduga semakin tinggi pula kualitas bermain alat musik organ mahasiswa. Jadi dapat diduga bahwa terdapat pengaruh yang berarti antara pemanfaatan sumber belajar perpustakaan terhadap hasil belajar bermain alat musik organ mahasiswa.

\section{Pengaruh Antara Pengetahuan Teori Musik Dengan Bermain Alat Musik Organ}

Memperdebatkan antara perlunya belajar teori musik dan tidak sama saja dengan mempermasalahkan duluan mana antara telur dan ayam. Karena banyak contoh dalam kenyataan bahwa banyak pemusik otodidak dengan sukses tanpa mengenal teori musik sedikitpun, dan dilain pihak banyak juga pemusik yang sukses karena berbekal pengetahuan akan teori musik yang mumpuni.

Penulis ingin mengingatkan sekaligus juga menekankan bahwa pilihan pertama yaitu menjadi sukses tanpa perlu belajar teori musik sangat dipengaruhi oleh faktor keberuntungan. Sedangkan dengan pilihan kedua yaitu menjadi pemusik sukses dengan bekal teori musik yang mumpuni dari jenjang pendidkan musik yang benar. Meski faktor keberuntungan tetap ada, namun sangat kecil pengaruhnya terhadap kesuksesan dengan belajar musik. 
Karena kerja keras kita dalam mempelajari teori musik pada akhirnya bukan pekerjaan yang sia-sia. Sebab hasil belajar akan menjadi kesuksesan dalam bidang musik. Kemampuan yang terasah dengan latihan musik akan semakin lengkap jika berbekal teori music yang benar. Di samping sebagai pemain musik kita juga bisa mengamalkan ilmu musik dengan menjadi instruktur musik, composer atau arranger handal, bahkan bisa menulis tentang teori musik dalam bentuk buku musik.

Pengetahuan teori musik merupakan kemampuan koognitif yang paling mendasar atau merupakan fundasi untuk mempelajari dan dapat bermain alat musik. Mahasiswa yang memiliki penguasaan teori musik yang baik dapat memberikan penjelasan tentang konsep-konsep umum dalam memainkan dan menganalisis reportoar musik, serta sanggup menjelaskan caracara mengaransemen musik baik secara teori dalam bentuk menjawab soal-soal teori musik maupun menggunakan instrument musik secara langsung.

Melalui metode pembelajaran yang bersifat edukatif dan didukung oleh media serta sarana dan prasaranan belajar yang memadai, diharapkan penyampaian teori musik akan dapat lebih mudah diserap oleh para mahasiswa. Untuk itu kreativitas dosen juga memegang peranan penting sehingga penyampaian materi teori musik tidak terkesan monoton melainkan justru meningkatkan minat serta motivasi belajar para mahasiswa untuk mempelajari teori musik yang pada hakikatkan akan meningkatkan hasil belajar teori musik bagi para mahasiswa tersebut.

Dengan demikian bahwa semakin efektif pembelajaran teori musik, maka akan meningkatkan pengetahuan teori tentang bermain alat musik organ dan diduga semakin tinggi pula hasil belajar bermain alat musik organ mahasiswa tersebut. Jadi dapat diduga bahwa ada hubungan antara pengetahuan teori musik dan hasil belajar bermain alat musik organ mahasiswa.

\section{PENUTUP}

\section{Simpulan}

Dari hasil penelitian dan pembahasan yang telah dilakukan terhadap mahasiswa/i Jurusan Pendidikan Musik Gerejawi di IAKN Tarutung mengenai hubungan pemanfaatan sumber belajar perpustakaan dan pengetahuan tentang teori musik dengan hasil belajar teori musik menghasilkan kesimpulan :

Secara parsial variabel pemanfaatan sumber belajar perpustakaan berpengaruh positif dan signifikan terhadap hasil belajar teori musik. Kondisi ini berarti hipotesis $\mathrm{H}_{\mathrm{a}} 1$ diterima. Secara parsial variabel pengetahuan tentang teori musik berpengaruh positif dan signifikan terhadap hasil belajar teori musik. Kondisi ini berarti hipotesis $\mathrm{H}_{\mathrm{a}} 2$ diterima. Secara simultan variabel pemanfaatan sumber belajar perpustakaan dan variabel pengetahuan tentang teori musik berpengaruh positif signifikan terhadap hasil belajar teori musik. Kondisi ini berarti hipotesis $\mathrm{H}_{\mathrm{a}} 3$ diterima. 


\section{Saran}

Dari kesimpulan yang telah diuraikan, maka peneliti memberikan beberapa saran:

Pemanfaatan sumber belajar perpustakaan merupakan salah satu variabel yang memiliki pengaruh dominan. Oleh karena itu kampus IAKN Tarutung harus senantiasa memperhatikan perpustakaan sebagai salah satu ikon yang mendukung kemajuan proses belajar mahasiswa mahasiswi IAKN Tarutung. Dengan meningkatkan kenyamanan dan fasilitas perpustakaan, meningkatkan kualitas buku dengan menyediakan banyak buku baru yang memiliki tahun terbit 5 tahun terakhir, agar ilmu-ilmu yang telah di perbaharui dapat di update oleh mahasiswa. Pengetahuan tentang teori musik juga merupakan salah satu variabel yang memiliki pengaruh. Oleh karena itu, para dosendosen kampus IAKN Tarutung harus dapat memberikan ilmu pengetahuan tentang teori musik yang benar terhadap mahasiswa/i jurusan pendidikan musik gerejawi. Dengan selalu update tentang musik gerejawi, mengajarkan mahasiswa baik teori dan praktik, memberikan kesempatan pada mahasiswa untuk belajar memainkan alat musik organ lebih intens. Bagi peneliti selanjutnya disarankan dapat menambah variabel independen yang akan diteliti seperti variabel motivasi belajar yang diperkirakan dapat mempengaruhi hasil belajar teori musik. Teknik analis data digunakan adalah uji kuesioner serta study kepustakaan. Uji normalitas, uji multikolinieritas, uji heterokedastisitas, uji analisis regresi, linear berganda, uji hipotesis yang terdiri dari uji $t$ uji $f$ dan uji koevisien determian $\mathrm{R}^{2}$. Berdasarkan hasil diperoleh persamaan regresi sebagai berikut: Hasil Belajar Teori Musik $=4,165+0,250(\mathrm{X} 1)+$ $0,010(\mathrm{X} 2)+\mathrm{E}$.

\section{DAFTAR PUSTAKA}

Anni Chatarina Tri. 2006. Psikologi Belajar.Semarang: UPT UNNES Press.

Bafadal, Ibrahim. 2006. Pengelolaan perpustakaan sekolah. Jakarta : Bumi Aksara.

Miarso, Yusuf Hadi. 2000. Makalah pusat sumber belajar. Jakarta . Rajawali.

Nakagawa, Shin. 2000. Musik dan Kosmos: sebuah pengantar Etnomusikologi. Jakarta: yayasan obor.

Sardiman, A.M. 2004. Intraksi dan motivasi belajar mengajar. Jakarta : Raja Grapindo Perkasa.

Soemanto, Wasty.2003. Psikologi pendidikan. Malang: Rhineka Cipta

Sunarto. 2002. Perkembangan Peserta didik. Jakarta Rhineka Cipta.

Sutarno. 2003. Perpustakaan dan Masyarakat. Jakarta: Yayasan Obor Indonesia. 
Syariffuddin dan Iwan Nasution. 2005. Manajemen Pembelajaran. Ciputat Quantum Teaching.

Tampubolon, Intan. 2009. Teori dasar musik I-II, Bahan kuliah. Medan: Jurusan Sendratasik Fakultas Bahasa dan Seni Unimed.

Simamora, Lince RT. 2006. Hubungan penguasaan teori musik dan frekuensi latihan dengan kemampuan bermain saksofon siswa SMKN 11 Medan. Tesis. Medan. Pascasarjana Unimed 